Int. J. Morphol.,

32(2):690-694, 2014.

\title{
Morphological Differences of Elite Bosnian Basketball Players According to Team Position
}

\author{
Diferencias Morfológicas de los Jugadores de Baloncesto \\ Bosnios de Elite según sus Posiciones de Equipo
}

\author{
Haris Pojskic",**; Vlatko Separovic*; Melika Muratovic,*** \& Edin Uzicanin,*,**
}

\begin{abstract}
POJSKIC, H.; SEPAROVIC, V.; MURATOVIC, M. \& UZICANIN, E. Morphological differences of elite Bosnian basketball players according to team position. Int. J. Morphol., 32(2):690-694, 2014.

SUMMARY: The aim of this research was the estimation of anthropometric characteristics of elite male basketball players from four Bosnian first league teams, as well as the identification of possible differences between players who play in different positions in the teams. Fifty-five, healthy players (age: $19.09 \pm 3.13$ years; body height: $189.13 \pm 8.30 \mathrm{~cm}$; body mass: $83.42 \pm 12.48 \mathrm{~kg}$ ) were divided into three different subsamples according to their positional role (twenty two guards, nineteen forwards and fourteen centers). Twenty morphological variables were measured and afterwards one (BMI) was calculated. For all anthropometric characteristics, descriptive parameters (mean, standard deviation and range) were calculated. In order to determine the possible differences between the players that play in different positions in the teams the analysis of variance (ANOVA) with Bonferoni post-hoc test for multiple comparisons was used. The results obtained show that there are significant differences between the different groups of players in sixteen out of twenty-one measured variables. Centers (big players) are dominantly heavier, taller, with longer and wider skeletons dimensionality as well as with bigger body circumferences compared to forwards and guards. Forwards are significantly heavier and taller with longer leg and arm lengths compared to guards. There are no significant differences between the groups in terms of body fat percentage, fat free percentage, body mass index and biepicondylar breadth of the femur and humerus. Generally, the values of the measured variables rise from guards to centers, except for body fat percentage and skinfolds. The obtained information can help coaches to indirectly evaluate fitness levels of the players and to design training and nutritional programs for basketball players.
\end{abstract}

KEY WORDS: Body composition; Anthropometrics; Positional role; Fat percentage.

\section{INTRODUCCIÓN}

Basketball has been described as an intermittent sport, being physically very demanding, requiring players to permanently repeat bouts of intense actions (sprinting, shuffling, jumping) with jogging, walking, or short periods of recovering between (Ben Abdelkrim et al., 2007; McInnes et al., 1995). It is also a game of continuously changing tempo, requiring the fast and explosive application of basketball techniques such as rebounding, driving, lay-ups, jump shooting, shot blocking, fast breaks and high speed play involving aerobic and anaerobic energetic processes (Maud \& Foster, 2006; Narazaki et al., 2009; Tessitore et al., 2006). Consequently, in order to play successfully, basketball players must develop a high level of physical fitness, that is to say their body composition, aerobic and anaerobic capacities, muscular power and strength have to be suitable for their team positional role.
Usually players from different team positions have differently developed physical fitness levels, as well as different body compositions and morphological profiles. Generally, basketball players can be classified into three team positions (guards, forwards and centers). Guards are in the main the shortest and fastest players in the team with the best ball control, while the centers are the tallest and the slowest players on the team. Recent studies that have investigated the differences between the players who play in different team positions have shown that the centers were taller and heavier, and had a higher body fat percentage (Jelicic et al., 2002; Sallet et al., 2005; Ostojic et al., 2006; Ben Abdelkrim et al., 2010) than the guards and forwards, but the guards had better aerobic and anaerobic capacities (Latin et al., 1994; Sallet et al.; Ostojic et al.; Cormery et al., 2008; Ben Abdelkrim et al., 2010), speed and agility

\footnotetext{
* School of Physical Education and Sport, University of Tuzla, Bosnia and Herzegovina.

** Center for Sports Excellence, Tuzla, Bosnia and Herzegovina.
} 
(Ben Abdelkrim et al., 2010; Tsitskaris et al., 2003), while the forwards and centers were better in muscular strength and absolute power (Ben Abdelkrim et al., 2010; Ostojic et al.).

Knowing the morphological profile of basketball players is very important because some of the anthropometric characteristics are highly genetically conditioned and consequently, they cannot be largely affected by any sport activity or training program. However, others are not so dependent on hereditary characteristics, and so can be changed. This knowledge can also help coaches to predict physical fitness levels as well as their motor and technical performance. In that regard, a higher body fat percentage can negatively contribute to speed, agility and lower-limb explosive power, and to basketball specific tasks i.e. in all activities where body mass is repeatedly lifted against gravity (Ben Abdelkrim et al., 2010; Apostolidis et al., 2004). Additionally, the elite players are able to be differentiated from others according to anthropometric and physiologic characteristics (Ben Abdelkrim et al., 2010), which can provide a better selection of talented players.

Unfortunately, to our knowledge there is a lack of studies carried out on Bosnian basketball players aiming to profile their morphological status. In that regard we measured anthropometric characteristics of fifty-five players from four Bosnian basketball teams. Therefore, the aim of this research was to determine the morphological profile and differences between elite Bosnian players according to their positional role. According to the different team roles, we hypothesized that the players would differentiate in their anthropometric characteristics.

\section{MATERIAL AND METHOD}

Fifty-five healthy basketball players (age: $19.09 \pm 3.13$ years; body height: $189.13 \pm 8.30 \mathrm{~cm}$; body mass: $83.42 \pm 12.48 \mathrm{~kg}$ ) from four teams of the Bosnian Premier League voluntarily participated in the study. All of them were healthy without any history of neuromuscular diseases or reported injury in the previous six months. At the time of research they had $7.5 \pm 2.6$ years of competitive experience. According to their clubs' head coaches, they trained 10 hours a week ( 5 sessions of 2 hours each) on court, improving technical and tactical skills, and 4.5 hours a week ( 3 sessions of 1.5 hours each) off court in the gym improving their strength, power and endurance, with a basketball game played every Saturday or Sunday. Players were told they were free to withdraw from the study at any time without penalty. Written informed consent was received from all players after a detailed verbal and written explanation of the experimental design, the purpose of the study, testing protocols, research benefits and potential risks of the study. The study was approved by the Ethical committee of the Tuzla University and conformed to the principles of the Declaration of Helsinki on human experimentation (World Medical Association, 2000).

For the estimation of the players' anthropometric characteristics, the following variables were measured: body height, body weight, body fat percentage, fat free mass percentage, hand length, foot length, leg length, arm length, biacromial breadth, bitrochanter breadth, biepicondylar breadth of the femur, biepicondylar breadth of the humerus, hand breadth, thigh girth, calf girth, upper arm girth, fore arm girth, subscapular skinfold, triceps skinfold and abdominal skinfold. Based on these measures we calculated the body mass index (BMI) for each player (body weight $(\mathrm{kg}) /$ body height $\left(\mathrm{m}^{2}\right)$.

Body height was measured to the nearest $0.01 \mathrm{~m}$ with a portable stadiometer (Astra scale 27310, Gima, Italy). Body weight, body fat percentage and fat free mass were measured using a bioelectric body composition analyzer (Tanita TBF300 increments $0.1 \%$; Tanita, Tokyo, Japan). Body girths were measured with anthropology measuring tape, skinfolds with a Harpenden skinfold caliper, biepicondylar breadth of the humerus and femur were measured with a spreading caliper and segmental lengths were measured with an anthropometer (Martin type). All the measurement procedures were accomplished in accordance with Eston \& Reilly (2009).

Descriptive statistics (mean, standard deviation, and range) were calculated for each variable. Data sets were checked for normality using the Kolmogorov-Smirnov test and by the visual observation of normality plots. Reliability and validity were assessed with an intraclass correlation coefficient (ICC) and Coefficient of Variation (CV). Levene's test was utilized to test for homogeneity of variances. In order to determine the possible differences between the players that play in different positions in the teams, the analysis of variance (One way - ANOVA) with Bonferroni post hoc test for multiple comparisons was used. The significance for all statistical tests was set at $\mathrm{p} \leq$ 0.05 . All statistical analyses were completed with the SPSS software statistical package (SPSS Inc., Chicago, IL; Version 14.0).

\section{RESULTS}

The results of the Kolmogorov-Smirnov test suggested no violation of the assumption of normality. Data 
showed good internal consistency and reliability. Values for Levene's test suggested no violation of the assumption of homogeneity of variance. Results from the one-way ANOVA showed that there was a significant difference in sixteen out of twenty-one variables between the groups. There were no significant differences in body fat percentage, fat free mass percentage, body mass index and biepicondylar breadth of the femur and humerus.
Table I shows Mean \pm Standard deviation and minimum and maximum of the players' anthropometric characteristics. Bonferroni post-hoc tests for multiple comparisons showed that guards were significantly different in sixteen out of twenty-one variables compared to the centers, but only four variables differentiated them from the forwards. On the other hand, the forwards were significantly different in thirteen out of twenty-one variables compared to the centers.

Table I. Mean \pm Standard Deviation and (ranges, minimum and maximum) of the anthropometric characteristics for players of different positional role.

\begin{tabular}{|c|c|c|c|}
\hline Variables & $\begin{array}{l}\text { Guards } \\
(n=22)\end{array}$ & $\begin{array}{c}\text { Forwards } \\
(n=19)\end{array}$ & $\begin{array}{l}\text { Centers } \\
(n=14)\end{array}$ \\
\hline Body height (cm) & $182.88 \pm 6.10(171.0-191.6)^{\dagger *}$ & $190.02 \pm 6.58(176.0-201)^{\dagger}$ & $197.75 \pm 4.40(191.8-206.2)$ \\
\hline Body weight (kg) & $77.38 \pm 11.36(58.8-96.6)^{\dagger^{*}}$ & $81.48 \pm 9.33(68.0-100.9)^{\dagger}$ & $95.55 \pm 9.61(77.7-112)$ \\
\hline Body fat percentage $(\%)$ & $12.41 \pm 4.19(6.1-19.5)$ & $12.28 \pm 3.05(8.1-17.8)$ & $15.04 \pm 4.64(5.5-24.2)$ \\
\hline Fat free mass percentage $(\%)$ & $87.58 \pm 4.18(80.5-93.88)$ & $87.70 \pm 3.05(82.14-91.88)$ & $84.94 \pm 4.64(75.8-94.47)$ \\
\hline Body mass index $\left(\mathrm{kg} \cdot \mathrm{m}^{-2}\right)$ & $23.06 \pm 2.61(18.8-27.0)$ & $22.57 \pm 2.49(18.1-28.5)$ & $24.60 \pm 2.76(19.4-30.4)$ \\
\hline Hand length $(\mathrm{cm})$ & $19.66 \pm 2.26(17.8-29.2)^{\dagger}$ & $19.90 \pm 0.92(18.5-21.9)$ & $20.52 \pm 0.84(19.3-22.7)$ \\
\hline Foot length $(\mathrm{cm})$ & $27.72 \pm 1.51(23.3-30.0)^{\dagger}$ & $28.60 \pm 1.26(26.8-31.1)^{\dagger}$ & $29.91 \pm 0.83(28.7-32.0)$ \\
\hline Leg length $(\mathrm{cm})$ & $93.96 \pm 4.40(85.9-101.8)^{\dagger^{*}}$ & $99.22 \pm 5.45(89.1-110.7)^{\dagger}$ & $103.83 \pm 2.67(98.6-109.3)$ \\
\hline Arm length $(\mathrm{cm})$ & $81.07 \pm 4.12(75.3-91.2)^{\dagger^{*}}$ & $83.78 \pm 4.60(78.6-96.7)^{\dagger}$ & $87.40 \pm 3.15(81.2-94.1)$ \\
\hline Biacromial breadth $(\mathrm{cm})$ & $41.25 \pm 3.55(36.2-52.0)^{\dagger}$ & $41.71 \pm 1.69(37.6-44.9)^{\dagger}$ & $44.58 \pm 1.42(42.2-47.4)$ \\
\hline Bitrochanter breadth $(\mathrm{cm})$ & $28.91 \pm 1.66(25.8-31.2)^{\dagger}$ & $30.06 \pm 1.47(27.8-33.4)^{\dagger}$ & $32.14 \pm 1.94(28.8-35.3)$ \\
\hline Biepicondylar breadth of the humerus $(\mathrm{cm})$ & $6.96 \pm 1.14(6.3-12.0)$ & $7.00 \pm 0.44(5.9-7.7)$ & $7.25 \pm 0.27(6.6-7.7)$ \\
\hline Hand breadth $(\mathrm{cm})$ & $8.29 \pm 0.55(7.4-9.6)^{\dagger}$ & $8.54 \pm 0.43(7.6-9.4)$ & $8.92 \pm 0.41(7.8-9.6)$ \\
\hline Thigh girth $(\mathrm{cm})$ & $55.01 \pm 3.94(48.8-62.0)^{\dagger}$ & $55.93 \pm 4.80(50.0-68.4)$ & $60.15 \pm 8.84(52.5-87.8)$ \\
\hline Calf girth (cm) & $38.27 \pm 2.22(34.0-42.5)^{\dagger}$ & $38.80 \pm 2.79(34.3-45.0)^{\dagger}$ & $41.15 \pm 2.22(38.4-45.4)$ \\
\hline Upper arm girth & $29.06 \pm 2.77(23.0-35.4)^{\dagger}$ & $28.57 \pm 2.47(25.4-33.5)^{\dagger}$ & $31.32 \pm 2.82(25.5-35.0)$ \\
\hline Fore arm girth $(\mathrm{cm})$ & $26.21 \pm 1.75(23.0-31.0)^{\dagger}$ & $26.51 \pm 1.90(23.5-30.6)^{\dagger}$ & $28.20 \pm 1.71(24.8-31.0)$ \\
\hline Subscapular skinfold (mm) & $10.76 \pm 3.78(6-21)^{\dagger}$ & $10.79 \pm 2.42(7-17)^{\dagger}$ & $14.24 \pm 4.36(9-21)$ \\
\hline Triceps skinfold (mm) & $10.07 \pm 4.72(6-23)^{\dagger}$ & $11.97 \pm 4.20(5-20)^{\dagger}$ & $13.75 \pm 4.61(7-25)$ \\
\hline Abdomin al skinfold (mm) & $12.94 \pm 6.13(7-29)^{\dagger}$ & $13.00 \pm 5.30(6-24)^{\dagger}$ & $17.91 \pm 7.89(8-29)$ \\
\hline
\end{tabular}

$*=$ values significantly different from those obtained for forwards; $\mathrm{p}<0.05 . \quad \dagger=$ values significantly different from those obtained for centers; $\mathrm{p}<0.05$.

\section{DISCUSSION}

This is one of the rare studies carried out on Bosnian elite basketball players. The main finding of this research was the existence of differences in the morphological characteristics between players according to their positional role. Significant differences were found in sixteen out of twenty one measured anthropometric variables.

The centers were significantly taller and heavier which is in line with previous studies (Latin et al.; Jelicic et al.; Ostojic et al.; Ben Abdelkrim et al., 2010). The centers' morphological characteristics determine their role in the game i.e. a low-post position. This means that they usually play near or inside the painted area, trying to get rebounds, score points close to the basket and block opponents' shots. They use their heavier bodies, body inertia and strength to efficiently complete their tasks during the games which involve a lot of contact with the opponent's players. Using their body weight, they efficiently set the screens and boxout opponent players.

Interestingly, comparing the results of the present study to the recent studies, there were some discrepancies. 
Although the values of body composition, body mass index, body fat percentage, fat free mass percentage (measured by bioelectric impedance) were higher in centers compared to the other groups, no significant differences were found between the groups. On the other hand there were small, but significant differences, in the values of skin folds obtained from three different body sites. The reason for this could be the inconsistency of the different measuring methods. All in all, the small differences found between the groups in the body composition variables can be attributed to welldesigned strength and conditioning programs for all players, which decrease the chances of body fat being stored differently in players according to their team role.

Additionally, the centers had longer and wider skeleton dimensionality, as well as bigger body circumferences compared to the forwards and guards. Their longer and bigger arms and legs can provide them with dominance under the basketball hoops compared to the guards and forwards. They get rebounds and scores under the basket more easily, and more easily block the opponents' shots than smaller players.

Consequently, the guards were smaller and lighter then the centers and forwards. This fact is in line with the studies mentioned earlier. Also, the guards had shorter and narrower skeleton dimensionality, as well as smaller body circumferences compared to the centers. Compared to the forwards, they had shorter legs and arms. This smaller body dimensionality and consequently lower center of body mass equip the guards with better ball handling, speed and agility with and without the ball. These anthropometric characteristics also mean that they are able to control the tempo of the game by fast dribbling and transitions as well as making easy scoring opportunities for their teammates.

This research data showed that the all groups of players are shorter and lighter compared to the players measured in previous studies (Ostojic et al.; Sallet et al.; Ben Abdelkrim et al., 2010). This can be explained by the players' age, as they are younger in the present study compared to the other studies. It is likely that their maturity has not yet finished and will continue after the age of twenty (Tanner, 1962). Also, the present study showed quite similar results regarding body fat percentage and fat free mass for the guard and forwards and some higher values for the centers (Ostojic et al.; Sallet et al.; Ben Abdelkrim et al., 2010; Garrido-Chamorro et al., 2012). This small discrepancy in adiposity tissue can be explained by the smaller number of games played, smaller training volumes and the intensity of this research compared to players involved in recent studies, who competed internationally, at higher levels, with their clubs.
From these results, and from the fact that there were significant differences between the players in their morphological characteristics according to their positional role, it can be concluded that our hypothesis has been confirmed. The current study proved once more that morphological characteristics determine a player's role in the team. Also this research gives very valuable anthropometric data for Bosnian players according to their specific positional role. The information obtained can help coaches in the selection process indirectly by evaluating the fitness level of their players. In addition, the data can be used for design training and nutritional programs specific for each player according to his positional role.

ACKNOWLEDGMENTS. The authors would like to thank the players and coaches from four Bosnian basketball teams (Celik-Zenica, Sloboda-Tuzla, Student-Tuzla, FalconsTuzla) for their participation in the study. We would also like to thank Tuzla University's School of Physical Education and Sport as well as the faculty staff for their assistance in performing this study.

POJSKIC, H.; SEPAROVIC, V.; MURATOVIC, M. \& UZICANIN, E. Diferencias morfológicas de los jugadores de baloncesto bosnios de elite según sus posiciones de equipo. Int. $\boldsymbol{J}$. Morphol., 32(2):690-694, 2014.

RESUMEN: El objetivo fue estimar las características antropométricas de los jugadores de baloncesto de elite en cuatro equipos bosnios de primera liga. Además, fueron identificadas las posibles diferencias entre los jugadores que ocupan distintas posiciones en los equipos. Fueron evaluados 55 jugadores sanos (edad: $19,09 \pm 3,13$ años; altura del cuerpo: $189,13 \pm 8,30 \mathrm{~cm}$; masa corporal: $83,42 \pm 12,48 \mathrm{~kg}$ ) se dividieron en tres submuestras diferentes de acuerdo a su rol posicional (22 guardias, 19 aleros y 14 centros). Se midieron 20 variables morfológicas y luego se calculó el IMC y otros parámetros descriptivos (media, desviación estándar y rango) para todas las características antropométricas. Para determinar las posibles diferencias entre los jugadores que juegan en distintas posiciones se utilizó el análisis de varianza (ANOVA) con la prueba post-hoc de Bonferoni de comparaciones múltiples. Existen diferencias significativas en dieciséis de las veintiuna variables medidas entre los diversos grupos de jugadores. Los jugadores de centro son predominantemente más pesados y más altos, con una dimensión de esqueleto más amplia, como también una circunferencia corporal mayor, en comparación con jugadores en posiciones forwards y guardias. Los delanteros son significativamente más pesados y más altos con un largo mayor de piernas y brazos en comparación con los guardias. No existen diferencias significativas entre los grupos en términos de porcentaje de grasa corporal, porcentaje de grasa, IMC y la amplitud bicondilea del fémur y húmero. Con excepción del porcentaje de grasa corporal y pliegues cutáneos, los valores de las variables medidas aumentan desde los jugadores guardias a los jugadores de centro. 
Esta información puede ayudar a los entrenadores a evaluar los niveles de aptitud de los jugadores, como también en la planificación de capacitación y programas de nutrición para los jugadores de baloncesto.

PALABRAS CLAVE: Composición corporal; Antropometría; Rol posicional; Porcentaje de grasa.

\section{REFERENCES}

Apostolidis, N.; Nassis, G. P.; Bolatoglou, T. \& Geladas, N. D. Physiological and technical characteristics of elite young basketball players. J. Sports Med. Phys. Fitness, 44(2):157-63, 2004.

Ben Abdelkrim, N.; El Fazaa, S. \& El Ati, J. Time-motion analysis and physiological data of elite under-19-year-old basketball players during competition. Br. J. Sports Med., 41(2):69-75, 2007.

Ben Abdelkrim, N.; Chaouachi, A.; Chamari, K.; Chtara, M. \& Castagna, C. Positional role and competitive-level differences in elite-level men's basketball players. J. Strength Cond. Res., 24(5):1346-55, 2010.

Cormery, B.; Marcil, M. \& Bouvard, M. Rule change incidence on physiological characteristics of elite basketball players: a 10year-period investigation. Br. J. Sports Med., 42(1):25-30, 2008.

Eston, R. \& Reilly, T. Kinanthropometry and exercise physiology laboratory manual: tests, procedures, and data. $3^{\text {rd }}$ ed. Routledge, The Taylor \& Francis, 2009.

Garrido-Chamorro, R.; Sirvent-Belando, J. E.; González-Lorenzo, M.; Blasco-Lafarga, C. \& Roche, E. Skinfold sum: reference values for top athletes. Int. J. Morphol., 30(3):803-9, 2012.

Jelicic, M.; Sekulic', D. \& Marinovic', M. Anthropometric characteristics of high level European junior basketball players. Coll. Antropol., 26(Suppl.):69-76, 2002.

Latin, R. W.; Berg, K. \& Baechle, T. Physical and performance characteristics of NCAA division I male basketball players. $J$. Strength Cond. Res., 8(4):214-8, 1994.

Maud, P. J. \& Foster, C. Physiological Assessment of Human Fitness. $2^{\text {nd }}$ ed. Champaign, Human Kinetics, 2006.

McInnes, S. E.; Carlson, J. S.; Jones, C. J. \& McKenna, M. J. The physiological load imposed on basketball players during competition. J. Sports Sci., 13(5):387-97, 1995.

Narazaki, K.; Berg, K.; Stergiou, N. \& Chen, B. Physiological demands of competitive basketball. Scand. J. Med. Sci. Sports, 19(3):425-32, 2009.
Ostojic, S. M.; Mazic, S. \& Dikic, N. Profiling in basketball: physical and physiological characteristics of elite players. $J$. Strength Cond. Res., 20(4):740-4, 2006.

Sallet, P.; Perrier, D.; Ferret, J. M.; Vitelli, V. \& Baverel, G. Physiological differences in professional basketball players as a function of playing position and level of play. J. Sports Med. Phys. Fitness, 45(3):291-4, 2005.

Tanner, J. M. Growth at adolescence; with a general consideration of the effects of hereditary and environmental factors upon growth and maturation from birth to maturity. $2^{\text {nd }}$ ed. Oxford, Blackwell Scientific Publications, 1962.

Tessitore, A.; Tiberi, M.; Cortis, C.; Rapisarda, E.; Meeusen, R. \& Capranica, L. Aerobic-anaerobic profiles, heart rate and match analysis in old basketball players. Gerontology, 52(4):21422, 2006.

Tsitskaris, G.; Theoharopoulos, A. \& Garefis, A. Speed, speed dribble and agility of male basketball players playing in different positions. J. Hum. Mov. Stud., 45(1):21-30, 2003.

World Medical Association. World Medical Association Declaration of Helsinki: ethical principles for medical research involving human subjects. JAMA, 284(23):3043-5, 2000.

\section{Correspodence to: \\ Haris Pojskic, PhD \\ School of Physical Education and Sport \\ University of Tuzla \\ Center for Sports Excellence \\ 2. oktobra 1, 75000 Tuzla \\ BOSNIA AND HERZEGOVINA}

Phone/Fax: ++38735278536

Email: haris.pojskic@untz.ba

Received: 16-11-2013

Accepted: 01-02-2014 